\title{
Metastatic Paraganglioma
}

National Cancer Institute

\section{Source}

National Cancer Institute. Metastatic Paraganglioma. NCI Thesaurus. Code C133712.

A paragang lioma that has spread from its original site of growth to another anatomic site. 